\title{
The Foreign Policy of the Islamic Republic of Iran: Prospects for Change and Continuity
}

Vali Golmohammadi

Tehran University

\section{Review article of two books:}

1. Mahmood Sariolghalam, The Foreign Policy of the Islamic Republic of Iran: A Theoretical Revision and the Coalition Paradigm (Tehran: Center for Strategic Research, CSR Press, 2005, 236 pp.).

2. Shahram Akbarzadeh and Dara Conduit, eds. Iran in the World: President Rouhani's Foreign Policy (repr., Houndmills, Basingstoke, Hampshire; New York, NY: Palgrave Macmillan, 2016, 206 pp., USD 79.20, eBook).

\section{Introduction}

Over the past four decades, there have been a variety of trends and developments in the foreign policy of the Islamic Republic of Iran. Within a framework of basic principles and fundamentals, the various administrations have shown different tactical behaviors in their approach to foreign policy. Conversely, despite critical shifts and developments in the domestic, regional, and international stages, some behaviors have basically remained unchanged. Since the 1979 revolution, despite major changes in the dynamics of domestic politics, structural developments in neighboring regions (especially the Middle East), and a shift in the global balance of power, Iranian foreign policy priorities have proven considerably consistent. Several Iranian administrations, from former presidents Hashemi Rafsanjani and Mohammad Khatami to current President Hassan Rouhani, have sought different approaches, but they have failed to adapt a new vision; the main pillars of Iran's foreign policy_Pan-Islamist, Pan-Shia, anti-Western, anti-Imperialist, anti-Zionist and proResistance Front-have remained stable. Many scholars believe that Iranian foreign policy principles and practices have remained stable because they emphasize self-sufficiency, indigenization, exceptionalism, and resistance. ${ }^{1}$ Taken together, these principles intensify Iran's isolation in the international arena.

There are four key forces that illuminate the lack of dynamism in Iran's foreign policy. First, in the foreign policy decision-making process, there is a constitutional mandate that

Vali Golmohammadi, PhD, Lecturer, Faculty of World Studies, Tehran University and Visiting Scholar, Bilkent University, Ankara. Email: v.golmohammadi19@gmail.com. (1)

Seyyed Jalal Dehghani Firoozabadi, Foreign Policy of Islamic Republic of Iran [in Farsi] (Tehran: SAMT Publications, 2009), 14-29; Rouhollah Ramezani, An Analytic Framework for Examining the Foreign Policy of the Islamic Republic of Iran, trans. Ali-Reza Tayyib (Tehran: Ney Publication, 2009): 117-23; Mohammad-Kazem Sadjadpour, Conceptual and Research Frameworks for Examining the Foreign Policy of the Islamic Republic of Iran (Tehran: International and Political Studies Institute, 2007), 23-7. 
gives power to the office of the Iran's supreme leader, while limiting presidential power. The supreme leader emphasizes the preservation of the religious and ideological foundations of the 1979 revolution, while the president focuses on the country's internal and executive affairs; the constitution limits the president's influence over foreign policy. The second force is the prioritization of national security over other strategic interests. National securities, and the perceived threats of the United States' hostile policies, directly influence Iranian static foreign policy priorities. The third key force is Iran's ongoing international blockage by the West, and its need to keep pushing back. Iran has a fear of regime change as posed by the regional containment policy of Western powers. This is the reason why Iran has maintained its anti-Western/anti-American ideological stance. Finally, maintaining the domestic political order remains a primary driving force of Iran's ruling elite. 'Revolutionism' and pan-Shiism serve to continue Iran's revolutionary domestic political order, constructed in opposition to capitalism and imperialism. ${ }^{2}$ Theoretically speaking, while the international system and structural conditions drive Iran's foreign policy priorities, domestic political factors have also played a major role in shaping Iran's foreign policy over the past four decades.

In attempting to understand the nature of continuity and the possibility of change in Iran's foreign policy, many questions emerge from the literature: ${ }^{3}$ To what extent has there been continuity and change in Iran's foreign policy since the Islamic Revolution of 1979? What type of coalitions and geo-political logic would allow for shifts in Iran's foreign policy? Have reformist presidents created meaningful foreign policy change in Iran? Is Iran's new moderate president, Hassan Rouhani, able to initiate structural foreign policy change? What are the prospects for change in Iranian foreign policy? These theoretical and practical concerns highlight the need for stronger academic contribution on the main drivers that underlie Iran's foreign policy. This review article will focus on two frequently referenced books, both of which aim to provide answers from an Iranian viewpoint, to the previous questions.

\section{No Feasible Coalition Paradigm}

The Foreign Policy of the Islamic Republic of Iran: A Theoretical Revision and the Coalition Paradigm, authored in Persian by Mahmood Sariolghalam, professor of international relations at Shahid Beheshti University of Tehran, provides an empirical framework for understanding Iran's foreign policy coalition paradigm in a systematic way. In an attempt to study the possibility of changing the dominant paradigm of Iran's foreign policy, he seeks an answer to the following question: Considering the capacity and nature of the Islamic Republic of Iran, what type of coalition and transnational alliance, and based on which intellectual and geographical logic, is feasible within the framework of goals and national strategy of the country? In order to find an answer to this question, he raises sub-questions regarding the possibility of developing coalitions and alliances with neighboring southern regions, the Islamic bloc, northern neighbors, and the eastern geographical areas, to meet the major

\footnotetext{
2 Mahmood Sariolghalam, "Prospects for Change in Iranian Foreign Policy," Carnegie Endowment for International Peace, February 20, 2018.

3 Amir Mohammad Haji Yousefi, "The Prospect of Iranian Foreign Policy: Interaction or Confrontation," in Iran, Politics and Future Studies, ed. Mojtaba Maghsoudi (Tehran: University Press Publications, 2012), 64-72; Seyed Hossein Seifzadeh, Iranian Foreign Policy (Tehran: Mizan Publication, 2005); Seyed Jalal Dehghani Firoozabadi and Ali Akbar Assadi, "Revolution and Foreign Policy of Iran: The First Decade Revised," Iranian Review of Foreign Affairs 4, no. 1 (Spring 2013): 157-84; Seyed Javad Tahaii, "Imam Khomeini and the Foundations of the I.R.I's Foreign Policy," Foreign Relations International Quarterly 1, no. 1 (2009): 42-7.
} 
national goals of Iranian foreign policy. This book, presented in eight chapters, summarizes the results of a remarkable collection of the author's theoretical and empirical research.

In the second chapter, the author uses the political realism approach to distinguish what is and what should be: idealism in foreign policy leads to catastrophes and tragedies. He then combines decision-making theories and foreign policies at a tri-level analysis (bureaucracy, decision-making groups, and individuals) and concludes that the individual variable is vitally important in Iran's foreign policy decision-making process. Because of the legal and practical supremacy of agent over structure in Iran's political system, individuals rather than structures play a decisive role in formulating and implementing Iran's foreign policy. The scientific study of this domain and the individual decision-making structure in this field will have a positive impact on rational foreign policy. The author also believes that the Middle East region is at a "pre-positivistic" stage, where emotional and ideological decision-making is halting the path toward rational foreign policy.

From the point of view of Sariolghalam, the basic principles of Iranian foreign policy are based on the country's political geography, its enormous energy resources, its sensitivity to independence and national sovereignty, and the tendency of Iranian culture for Western science, technology, and culture. In the third chapter, the author classifies the macro-goals of Iranian foreign policy into three categories: (1) developing the economy and preserving territorial integrity and national sovereignty; (2) defending Muslims and liberation movements, and fighting against Israel and the West (especially the United States); (3) establishing an Islamic society based on Shi'a principles. Sariolghalam believes that reaching these goals depends on a transnational coalition and alliance as well as on rational decision-making in foreign policy.

In the next chapters, taking into account the neighboring regions, the author asks if cooperation, coalition, and alliance will ever be possible with the southern and northern regions, Islamic blocs, and the great eastern communities. He also questions to what extent this cooperation, coalition, and alliance could fulfill the macro-goals of Iran's foreign policy and national security. As for coalition and cooperation with the southern region of Iran (i.e., the Arabian Peninsula and the Persian Gulf), the author, after analyzing the regional state, conflicts in the Middle East, and the involvement of foreign forces in them, concludes that "deep instability and dependence" in the southern region of Iran is not contributing to the formation of such a coalition and strategic cooperation. In the northern regions, the fragile political-social state, intra-regional tensions, isolationism, and the economic capabilities of the Central Asian and South Caucasian republics represent the most important obstacles to the unification or coalition of Iran with these countries. As for attitudes toward the Islamic bloc, the author believes that distrust, the legitimation crisis, sectarianism, and deep ethnic and religious differences between Islamic countries on one hand, and the structural-security dependency of the majority of Islamic countries to the West on the other, have provided the political ground for the reluctance of these countries to develop economic cooperation, a security coalition, or a strategic partnership with Iran. In chapter seven, "Attitudes Towards the Great Eastern Community", the author deals with the socio-political developments in Afghanistan and Pakistan, and the structural instability in these countries; he conducts a comparative study of the capabilities of the great Asian powers, including Japan, China, India, and assesses Iran's strategic importance to them. He concludes that the great powers of Asia do not link Iran's activism in the Middle East to their security and economic destiny, and therefore feel no strategic need to establish a political coalition with Iran. It seems that Japan, 
China, and India only attach importance to Iran's capabilities in the field of energy exports, and it's role in oil transit and pricing in OPEC. ${ }^{4}$

Finally, Sariolghalam summarizes his research findings in three points. (1) As long as the legal foreign policy conflicts associated with the links between the ideological dimensions and the transnational dimension in the constitution of the Islamic Republic of Iran are not resolved, it will not be possible to design a theoretical and practical national strategy or develop a coalition and regional alliance. (2) All neighboring states to the Islamic Republic of Iran are either on the decline or have deep structural, political, and security dependency. Although temporary co-ordination with these countries and blocs is natural, regional coalitions and alliances will not be feasible. (3) The Islamic Republic of Iran does not have the foundations for an ideological transnational coalition with any other country in the region; revolutionary countries and countries who protest the international order, such as Iran, do not have the necessary foundation for economic, technological, scientific, and security exploitations on the international and regional stages. (4) The cultural, geographic, and economic characteristics of Iran make it impossible for the country to develop sustainable security coalitions at national and international levels. This feature represents Iran as an international political unit that must work with major powers to manage crises and regional issues, or to even play a significant regional role. (5) If the Islamic Republic of Iran manages to develop constructive relations with the great powers (especially the West), the key decision makers of Iran's foreign policy can then provide the groundwork for a security coalition in the Persian Gulf, political-economic alliance with Turkey, Egypt, Saudi Arabia, Syria, and Iraq (in order to confront Israel's growing regional power), a security coalition with India within the framework of eastern and northeastern security, an economic coalition with the GCC, and political and economic cooperation with Europe, Japan, and China.

Finally, considering the various periods, the dynamics of domestic politics and the political principles of the Islamic Republic of Iran regarding the possibility of change in Iran's foreign policy (especially on sensitive issues such as Iran-US relations), Sariolghalam concludes that no change is expected in the current Iranian foreign policy for three reasons: (1) the lack of a link between the country's foreign policy and the global economic system; (2) the ideological nature of sovereignty in the political system: (3) and the tendency to maintain existing foreign policy approaches by considering the interrelationships between legitimacy and national security and foreign policy. As long as Iran's domestic order is based on the religious and revolutionary ideological system, the foreign policy will contribute to the continuation of this revolutionary domestic order, and possible change in foreign policy will depend on changes in domestic politics. It seems that the author has managed to prove the research hypotheses by providing empirical evidence.

\section{An Illusory Chance for Change in Foreign Policy}

Iran in the World; President Rouhani's Foreign Policy, by Shahram Akbarzadeh and Dara Conduit, is an edited volume evaluating President Hassan Rouhani's foreign policy during his first two years in office. The book includes case studies of neighboring countries and American-Iranian relations by highlighting Iran's long-contentious nuclear issue. President Rouhani came to power in Iran in 2013 promising to reform the country's long-contentious 
foreign policy. Unlike Mohammad Khatami's liberal-pragmatic vision or Mahmoud Ahmadinejad's ideological-populist stance, Hassan Rouhani is bent on pursuing a centristpragmatic vision in Iran's foreign policy. Contrary to what many believe, Iran's foreign policy is not exclusively shaped within the context of Islamic discourse and ideology, fluctuating between revolutionary idealism and pragmatic realism. Pragmatism has always been an integral part of Iran's foreign directions, and can be traced in hotly-debated foreign policy issues like it's détente with the US or it's support of specific forces in the Levant, neither of which have ideological links to Iran. President Rouhani won the presidency primarily because he promised to bring a measure of rationality and pragmatism to Iran's inefficient foreign approaches. Unlike Ahmadinejad's revolutionary discourse and confrontational practice in foreign policy, President Rouhani's administration has pledged to de-securitize and normalize foreign relations, improve the deteriorating economic condition, end the longstanding nuclear dispute, and mend ties with neighboring countries.

In this timely volume, Akbarzadeh examines the Islamic Republic's foreign policy at a time of profound change and transition, highlighting some of the inherent tensions and milestones of the Rouhani administration as it charts a new course for Iran's regional and global roles. This book, which concentrates on elements of continuity, and domestic and external drivers of change, brings together many interesting insights of Iran's contemporary politics and foreign relations.

The first chapter of the book provides practical and theoretical questions regarding the possibility of meaningful change in Iran's foreign policy during Rouhani's first term in office; these enable the reader to have a general look at Iran's contemporary foreign policy. By looking at Rouhani's foreign policy toward neighboring countries, as well as the high-profile American-Iranian relationship, this volume addresses the following critical questions: Has Iran's new president created meaningful foreign policy change? Can Rouhani achieve a lasting rapprochement with the United States? Does Rouhani's experience of the presidency add greater depth to our understanding of Iranian foreign policymaking?

The book is composed of ten chapters, with an insightful discussion by Akbarzadeh in the first and tenth chapters. Akbarzadeh argues that as Rouhani came to power in 2013, despite Ahmadinejad's stubborn style, which had seriously damaged the country's international image, Iran has re-emerged as a regional power. Rouhani was widely hailed as a reformist who could improve Iran's international position by adapting a new pragmatic vision. However, he shows that for all of Rouhani's moderation, it would be naïve to expect that he would fundamentally undermine the Iranian theocratic system. Rouhani is a revolutionary and a regime insider who is deeply embedded in the Iranian political system.

Early in his presidency, Rouhani even enjoyed the support of the Supreme Leader, who articulated that the time had come for Iran to exercise "heroic flexibility" in foreign policy, especially on nuclear negotiations. Rouhani set out an ambitious plan for foreign policy reform in the first term that was defined by four inter-related themes: rebuilding the economy, resolving the nuclear issue, ending Iran's international isolation, and regional engagement. Rouhani quickly put these pledges into action by rebuilding relations with the US as his top priority. Within two months of inauguration, he had held a historic phone call with US President Barack Obama, becoming the first Iranian and US presidents to speak directly since the Iranian revolution in 1979. Over the following three years, Rouhani and Obama fomented an unprecedented thaw in American-Iranian relations, leading to a resolution of the 
nuclear issue known as the Joint Comprehensive Plan of Action (JCPOA) ${ }^{5}$ and a significant improvement in Iran's international reputation as Iran began welcoming western dignitaries to Tehran. Soon after, Rouhani and foreign minister Mohammad Javad Zarif started to normalize relations with neighbors, discussing friendship, and presenting Iran as the region's rational actor. This outreach was often complimented by soft power initiatives, especially through Iran's extensive regional network of charitable trusts. ${ }^{6}$

However, in spite of the Rouhani administration's efforts to formulate a new constructive vision in foreign policy, he faced enormous obstacles in domestic politics and in the international arena. According to Akbarzadeh, the international arena has presented a variety of challenges: the deteriorating situation in Syria, an increase in sectarian tensions across the region, the persistent security challenges in Afghanistan, and the hardening of Israel's stance on Iran. These issues have combined to create an inhospitable environment for Rouhani's planned détente. In the domestic sphere, which Akbarzadeh gives more weight to, Rouhani has encountered powerful domestic opponents, particularly among the Iranian Revolutionary Guards Corps (IRGC), Iran's conservative elites and hardliners in the parliament. Indeed, the interaction between Iran's chaotic domestic politics and the changing international environment has undermined Rouhani's diplomatic attempts and has imposed considerable barriers to pursuing his foreign policy agenda. Rouhani's foreign policy agency was further undermined after the meteoric rise of Jihadists (ISIS) in Iraq and Syria. This rise has quickly changed the domestic balance of power in favor of conservatives and hardliners in Iran, in particular the IRGC, who were running Iran's Middle East policy. As Akbarzadeh argues, it was expected that Rouhani would face a difficult path in foreign policy change. Unlike his two moderate predecessors, Mohammed Khatami and Hashemi Rafsanjani, Rouhani's legacy in Iranian politics is a poor one; while he continues to enjoy the support of the Supreme Leader, his legacies are faltering under the weight of conservative political pressure.

In the last chapter, by taking all the book's previous discussions into account, Akbarzadeh presents a general look at the prospects of Iranian foreign policy in Rouhani's presidency. He claims that while President Rouhani has made progress in the American-Iranina relationship, nuclear negotiations, and some bilateral relationships, his broader success has been hampered by regional political developments, particularly in the Middle East and the domestic politics competition. Further, Akbarzadeh contends that Rouhani's future success will be guided by emerging regional tensions, including whether Iran's neighbors will accept the terms of the nuclear agreement. Although Rouhani's election victory endowed him with the popular mandate to change the foreign policy of Iran, the newly elected reformist president faced no shortage of obstacles in the first two years of his presidency. He quickly discovered both internal and external barriers to bringing Iran out of international isolation and dealing with the country's long-standing issues. This is not to say that regional events, especially developments in Syria, Iraq, Yemen, and the Kurdish issue, completely thwarted Rouhani's efforts at re-engagement.

5 The Joint Comprehensive Plan of Action; known commonly as the Iran nuclear deal or Iran deal, is an agreement on the nuclear program of Iran reached in Vienna on 14 July 2015 between Iran, the P5+1 (the five permanent members of the United Nations Security Council — China, France, Russia, United Kingdom, United States — plus Germany), and the European Union.

6 Such as: Bonyad-e Farabi (Farabi Foundation), Bonyad-e Mosta'zafin va Janbazan (Foundation for the Oppressed and Disabled), Bonyad-e Panzdah-e Khordad (15 Khordad Foundation), Bonyad-e Resalat, Bonyad-e Sa'adi, Bonyad-e Shahid va Isargaran (Martyr's and Veterans' Foundation). Although all of these organizations were established outside the formal structures of the three branches of government, they were nonetheless linked to the formal structures. The mentioned bonyads perform not only humanitarian and economic functions inside Iran but also serve as a source of the Islamic revolution's soft power through various aid projects in strategically targeted countries, especially within Iran's neighborhood. 
From Akbarzadeh's point of view, Rouhani enjoyed some success on the international stage during his first two years in office. This included attaining détente with President Obama and signing the nuclear agreement (JCPOA-5+1 nuclear negotiations), both remarkable achievements that enabled Rouhani to reverse some of the damage that his predecessor had inflicted upon Iran's international reputation. However, Rouhani's diplomatic efforts to normalize relations with neighboring countries have been less successful. Afghanistan and Iraq see the benefits of mending relations with Iran, especially under the mild-mannered President Rouhani. However, Saudi Arabia and other Arab Sheikhdoms remain wary of Iran's regional ambitions, particularly after signing JCPOA; these ambitions continue to overshadow the relationships and impede Rouhani's constructive agendas in foreign policy. Regardless, progress on the country's most contentious nuclear issue and the prospect of sanctions relief galvanized Rouhani's popular mandate in domestic politics, and allowed him to keep his conservative critics at bay. Despite these historical achievements, the overall gains of Rouhani's moderate foreign policy agenda were considerably hampered by the developments in the Middle East and Persian Gulf. Iran's burgeoning influence failed to win it friends across the region, and Iran, under the Rouhani administration, faced trepidation by some neighbors and regional rivals like Saudi-Arabia, Turkey, and Israel. Further, the negative view of Iran as bent on destabilizing the region and expanding its influence through sub-state actors gained prominence in this period, particularly in the wake of Iran's support for both Shi'a militias and Hezbollah.

Under such critical circumstances in the region, as Akbarzadeh shows in his book, even the nuclear agreement, which had long been hailed as the key to regional stability in the Middle East, was perceived as a tool that would give Iran the green light for regional domination. Iran's regional competitors perceived an imminent threat from Iran, especially after the Resistance Front's operational progress in Syria and Iraq. In fact, it appeared that for many of Iran's Sunni neighbors, the combination of Iran's pariah status and the international sanctions regime had helped keep Iran in its box for the past decade. With the easing of economic sanctions, Iran would be able to exercise an increasingly assertive foreign policy, as already shown in Syria, Iraq, and Yemen. This was a major factor behind Saudi Arabia's decision to amass a Sunni coalition to repel the Houthi insurgency in Yemen. Likewise, ISIS's rise, although providing strategic spaces for Iran to maximize its structural power and influence on the regional stage, provided an impediment to Rouhani's strategic plan of international engagement. Many of the Arab states came to view Iran's role in Iraq through the lens of the Syrian conflict, where Iran had backed the Assad regime while the rest of the Arab states backed the largely Sunni opposition. As this book claims, while Iran and its neighbors were technically fighting on the same side of the battle against ISIS, as the group emerged, rather than highlighting shared interests, interstate and ideational rivalries deepened.

Domestic obstacles played a significant role in curtailing the complete realization of Rouhani's foreign policy program. While Rouhani was able to implement foreign policy change in Iran's relationships with Armenia, Azerbaijan, the UAE, and the KRG, he had little influence over the Iraq, Yemen, and Syria portfolio. This was because contemporary ties with Iran-Syria, Iraq, and Yemen have been characterized by military considerations, meaning that the IRGC has had the upper hand in the relationships for decades. In fact, Rouhani's near paralysis in this sphere illustrated the scale of limitations of presidential power in Iran, particularly in portfolios that fall within the strategic interests of the Supreme 
Leader Ayatollah Khamenei or the IRGC. It is highlighted in this chapter that Iran's problems no longer revolved exclusively around the nuclear issue, so signing a deal and reviving Iran's economy was only part of the challenge.

Rouhani's challenges were exacerbated by the fact that his success in dealing with some issues inadvertently intensified others. This has already been seen in Iran's progress on the nuclear issue, which in turn led to serious concerns in Tel-Aviv, Riyadh, and some other Arab capitals in which Rouhani's administration did not appear to have a clear strategy to alleviate the pervasive concerns over Iran's growing power throughout the neighboring regions. This book concludes that because of the significant limitations that president Rouhani has faced in the decision-making process of Iranian foreign policy, in particular on strategic issues, no considerable shift and change in Iran's foreign policy is expected (also the case in the former reformist administration).

\section{Concluding Remarks and the Way Forward}

As illustrated in the two books that were reviewed, Iran's foreign policy dynamics are products of overlapping, and sometimes contradictory, motivations, foundations, and actors. From the Iranian viewpoints, Iran's top decision-makers are apparently motivated, at least to some extent, by the perception of threat to their regime and their national interests. They surely believe that the US and other hostile powers in the region are pursuing a "regime change" strategy toward the Islamic Republic of Iran. This perception of threat significantly shapes Iran's static foreign policy behavior, in which no agency can shift its long-standing directions. Iran's foreign policy often appears to reflect differing approaches and outlooks among key players with highly different authority. Iran's Supreme Leader Ayatollah Ali Khamenei, who melds political and religious authority, has repeatedly stressed that the US has never accepted the Islamic revolution and seeks to overturn it through support for domestic opposition to the regime, imposition of economic sanctions, and support for Iran's regional adversaries. On the contrary, Iranian reformist leaders, especially president Hassan Rouhani, emphasize that Iran should not have any permanent enemies. He maintains that a pragmatic and constructive foreign policy will result in an easing of international sanctions under the JCPOA. To understand who is ultimately in charge of the decision-making, it should be noted that according to Iran's constitution and in practice, Iran's Supreme Leader has the final say over all major foreign policy decisions.

All in all, in spite of Rouhani's multilateral diplomatic efforts, Iran's foreign policy toward the US is characterized by significant continuity. On one hand, these are pertinent to Iran's reproduction of institutionalized images and its practices of enmity toward the US, and to the significant deficits of trust and mutual understanding between the two states since the 1979 Islamic Revolution. This reality identifies several changing power dynamics within the Iranian political spectrum, as well as significant geopolitical developments in the region, which are likely to act as long term 'push or pull' elements in formulating Iranian foreign policy; this limits the Rouhani administration's ability to maneuver in the course of foreign policy change. On the other hand, in attempting to negotiate with Iran, pressures and threats, direct or indirect, military, economic or diplomatic, can prove to be highly counterproductive.

Over the last four decades, in the internal structure of Iran there have been occasional flexibilities, some compromises, concessions, and balancing political acts in domestic politics with regards to culture, education, economy, and the social atmosphere. Ironically, the anti- 
American and anti-Israeli foundations of Iran's foreign policy behavior have remained solid and very consistent at the regional and international levels. Two separate illusions have overshadowed this Iranian foreign policy behavior: first, that the Muslim world will embrace Iranian foreign policy and the revolutionary message that has not yet been materialized; second, the illusion that began in the 1990s that Iran would be able to separate the American and European objectives, allowing Iran to build an alliance with European states separate from the US. Both illusions have failed in the way that Iran has conducted its foreign policy.

The anti-Western doctrine, regional activism (in particular in the Middle East), and developing nuclear capabilities, provided ample opportunities for Iran's foreign policy key decision-makers to maintain the configuration of power within Iran. In other words, Iranian foreign policy has been at the service of maintaining domestic political order instead of pursuing ideological objectives. This foreign policy behavior has been substantiated by ideological-religious narratives, populist impulse, political isolation, and a resistance to alliances to pursue national goals in the regional and at the international level. We need to then look at the foreign policy decision-making structure in Iran. The group that makes the decisions is fundamentally an introverted group with little global exposure, and has a domestic agenda separate from Iran's national economy due to limited alternative narratives.

To date, neither the JCPOA, nor the newly imposed American sanctions, nor any particular American policy or strategy in the region has reduced Iran's regional influence and changed its staunch foreign policy course. ${ }^{7}$ In the eyes of Iranian leaders, the American withdrawal from the JCPOA and the new economic sanctions that the Trump administration has placed on Iran are undoubtedly influenced by Israel and Saudi Arabia; both fear the growth of Iranian influence and power in the region. ${ }^{8}$ The immediate consequence is that Iran will be able to more freely pursue its nuclear program; this greatly alienates the US from its European allies over Iran's nuclear issue. Three EU signatories to JCPOA urge the US not to tear up the Iranian nuclear deal, and believe no better alternative has been suggested by the Trump administration. ${ }^{9}$ Growing tension between the Americans and Europeans on the Iranian nuclear deal is widening the strategic gap between the US and its EU allies over Iran's regional role, especially in the Middle East. ${ }^{10}$

Whether the JCPOA continues to operate despite the American's withdrawal, Iran will be an increasing challenge to the US and its regional allies' strategic interests in the Middle East, in particular in the Levant, Iraq, and Yemen. Although the American withdrawal from JCPOA has exacerbated Iran's economic conditions, it has led to greater unity in the domestic sphere. It has increased Iran's confidence in maintaining and maximizing its influence and power

7 Amy Myers Jaffe, "The Complicated Geopolitics of U.S. Oil Sanctions on Iran," Council on Foreign Relations, May 25, 2018, https://www.cfr.org/blog/complicated-geopolitics-us-oil-sanctions-iran.

8 Zack Beauchamp, "2 Winners and 5 Losers from Trump's Iran Deal Withdrawal,” VOX, May 8, 2018, https://www.vox. com/world/2018/5/8/17329052/iran-nuclear-deal-trump-winners-losers; Oliver Holmes, "Iran deal: How Trump's actions could flare violence in Middle East," The Guardian, May 9, 2018, https://www.theguardian.com/world/2018/may/09/iran-deal-howtrump-actions-could-flare-violence-in-middle-east; Adam Entous, "Donald Trump's New World Order: How the President, Israel, and the Gulf states plan to fight Iran — and leave the Palestinians and the Obama years behind," The New Yorker, June 18, 2018, https://www.newyorker.com/magazine/2018/06/18/donald-trumps-new-world-order.

9 Donald Trump has called JCPOA the "worst deal ever negotiated" and wanted Britain, France and Germany-co-signatories, along with Russia, China and the European Union — to toughen up its terms. For more information see: Alastair Jamieson, "Trump scraps the Iran nuclear deal. Now what?," NBC news, May 8, 2018, https://www.nbcnews.com/news/world/trump-scraps-irannuclear-deal-now-what-n872296.

${ }_{10}$ Parisa Hafezi and John Irish, "Europeans engage with Iran on regional issues as Trump deadline nears," Reuters, March 1, 2018, https://www.reuters.com/article/us-iran-nuclear-europeans/europeans-engage-with-iran-on-regional-issues-as-trumpdeadline-nears-idUSKCN1GD5TZ. 
to contain adversaries throughout the neighboring regions. In the predictable future, Iran's foreign policy priorities will most likely focus on a continued confrontation with the Western world, and the West's regional allies in the Middle East. Unless unexpected internal and external developments occur and a paradigm shift emerges, Iran's foreign policy—neither direct confrontation nor normalization with the West—will remain unchanged.

\section{Bibliography}

Akbarzadeh, Shahram, and Dara Conduit, eds. Iran in the World; President Rouhani's Foreign Policy. Reprint, Houndmills, Basingstoke, Hampshire; New York, NY: Palgrave Macmillan, 2016.

Dehghani Firouzabadi, Seyed Jalal. A Discursive Change in the I.R.I's Foreign Policy. Tehran: SAMT Publications, 2005.

. Foreign Policy of Islamic Republic of Iran [in Farsi]. Tehran: SAMT Publications, 2009.

Dehghani Firoozabadi, Seyed Jalal, and Ali Akbar Assadi. "Revolution and Foreign Policy of Iran: The First Decade Revised." Iranian Review of Foreign Affairs 4, no. 1 (Spring 2013): 157-84.

Haji Yousefi, Amir Mohammad. "The Prospect of Iranian Foreign Policy: Interaction or Confrontation.” In Iran,

Politics and Future Studies, edited by Mojtaba Maghsoudi, 117-165. Tehran: University Press Publications, 2012.

Jaffe, Amy Myers. "The Complicated Geopolitics of U.S. Oil Sanctions on Iran." Council on Foreign Relations, May 25, 2018. https://www.cfr.org/blog/complicated-geopolitics-us-oil-sanctions-iran.

Ramezani, Rouhollah. An Analytic Framework for Examining the Foreign Policy of the Islamic Republic of Iran. Translated by Ali-Reza Tayyib. Tehran: Ney Publication, 2009.

Sajadpour, Mohammad Kazem. Conceptual and Research Frameworks for Examining the Foreign Policy of the Islamic Republic of Iran. Tehran: International and Political Studies Institute, 2007.

Sariolghalam, Mahmood. The Foreign Policy of the Islamic Republic of Iran: A Theoretical Revision and the Coalition Paradigm. Tehran: Center for Strategic Research, CSR Press, 2005.

Seifzadeh, Seyed Hossein. Iranian Foreign Policy. Tehran: Mizan, 2005.

Tahaii, Seyed Javad. "Imam Khomeini and the Foundations of the I.R.I's Foreign Policy." Foreign Relations International Quarterly 1, no. 1 (2009): 24-59. 